\title{
(2) OPEN ACCESS \\ Acutely ruptured basilar artery bifurcation aneurysm, treated with simultaneous Cascade and Comaneci temporary-assisted coiling
}

\author{
Alexander Sirakov, ${ }^{1}$ Radoslav Raychev (D) , 2 Pervinder Bhogal, ${ }^{3}$ Stanimir Sirakov (D) ${ }^{1}$
}

\begin{abstract}
'Radiology Department, University Hospital Saint Ivan Rilski, Sofia, Bulgaria ${ }^{2}$ Neurology, University of California Los Angeles David Geffen School of Medicine, Los Angeles, California, USA ${ }^{3}$ Interventional Neuroradiology, Royal London Hospital, London, UK
\end{abstract}

\section{Correspondence to} Dr Stanimir Sirakov, Radiology Department, University Hospital Saint Ivan Rilski, Sofia 1431, Bulgaria; ssirakov@bsunivers. com

Received 7 May 2020 Revised 24 May 2020 Accepted 9 June 2020 Published Online First 21 July 2020
Check for updates

(C) Author(s) (or their employer(s)) 2021. Re-use permitted under CC BY-NC. No commercial re-use. See rights and permissions. Published by BMJ.

\section{To cite: Sirakov $A$}

Raychev R, Bhogal P, et al.

J Neurolntervent Surg

2021;13:196

\begin{abstract}
Temporary stent-assisted coiling is an eligible approach for the treatment of acutely ruptured complex cerebral aneurysms. Improved material properties and industrial advances in braiding technology have led to the introduction of new stent-like devices to augment endovascular coil embolization. Such technology includes the Cascade and Comaneci neck-bridging devices. Both devices are manually controlled, non-occlusive and fully retrievable neck-bridging temporary implants. The braided nature and the ultra-thin wire, compliant structure of their bridging meshes helps maintain target vessel patency during coil embolization. In this video (video 1) we demonstrate the straightforward combination of two temporary neck-bridging devices for the embolization of an acutely ruptured aneurysm of the basilar artery. Technical success and complete embolization of the aneurysm were recorded at the final angiography. In this technical video we discuss the technical nuances of the Comaneci and Cascade coil embolization.
\end{abstract}

Contributors AS, SS: case performance, video creation. PB, RR: final review.

Funding The authors have not declared a specific grant for this research from any funding agency in the public, commercial or not-for-profit sectors.

Competing interests None declared.

Patient consent for publication Not required.

Ethics approval Ethics Committee of University Hospital Saint Ivan Rilski approved on 06.05.2019 (ID: 314/06.05.2019) the information consent, including permission to use the data in scientific papers. All patient data are anonymized.

Provenance and peer review Not commissioned; externally peer reviewed.

Open access This is an open access article distributed in accordance with the Creative Commons Attribution Non Commercial (CC BY-NC 4.0) license, which permits others to distribute, remix, adapt, build upon this work non-commercially, and license their derivative works on different terms, provided the original work is properly cited, appropriate credit is given, any changes made indicated, and the use is non-commercial. See: http:// creativecommons.org/licenses/by-nc/4.0/.

\section{ORCID iDs}

Radoslav Raychev http://orcid.org/0000-0001-8463-0664 Stanimir Sirakov http://orcid.org/0000-0001-6034-5340

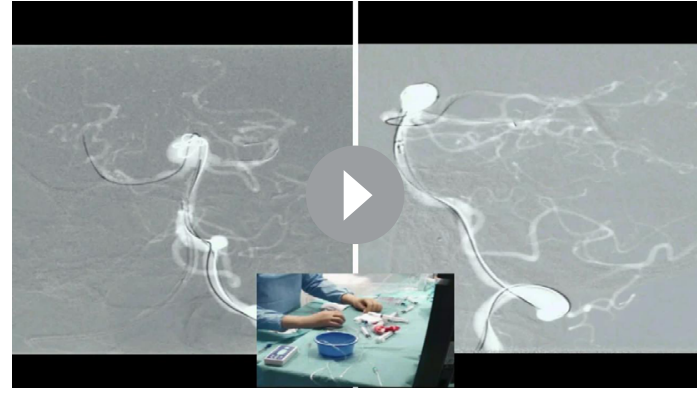

Video 1

\section{REFERENCES}

1 Schievink WI, Wijdicks EF, Piepgras DG, et al. The poor prognosis of ruptured intracranial aneurysms of the posterior circulation. $J$ Neurosurg 1995;82:791-5.

2 Bhogal P, Wong K, Makalanda H. The Cascade device - in vitro tests to assess coil protrusion into the parent vessel. Interv Neuroradiol 2020;159101992092570

$3 \mathrm{Ge} \mathrm{H}$, Lv X, Jin H, et al. The role of endovascular treatment in unruptured basilar tip aneurysms. Interv Neuroradiol 2017;23:8-13.

4 Molyneux A, Kerr R, Stratton I, et al. International Subarachnoid Aneurysm Trial (ISAT) of neurosurgical clipping versus endovascular coiling in 2143 patients with ruptured intracranial aneurysms: a randomised trial. Lancet 2002:360:1267-74.

5 Pérez MA, Bhogal P, Moreno RM, et al. Use of the pCONus as an adjunct to coil embolization of acutely ruptured aneurysms. J Neurointerv Surg 2017;9:39-44.

6 Bhogal P, Lylyk I, Chudyk J, et al. The Contour-early human experience of a novel aneurysm occlusion device. Clin Neuroradiol 2020;38 http://link.springer.com/

7 Bhogal P, Bleise C, Chudyk J, et al. The p48_HPC antithrombogenic flow diverter: initial human experience using single antiplatelet therapy. I Int Med Res 2020;48:580

8 Makalanda H, Wong K, Bhogal P. Flow-T stenting with the Silk Vista Baby and Baby Leo stents for bifurcation aneurysms - a novel endovascular technique. Interv Neuroradiol 2020;26:68-73.

9 Sirakov S, Sirakov A, Hristov $\mathrm{H}$, et al. Early experience with a temporary bridging device (Comaneci) in the endovascular treatment of ruptured wide neck aneurysms. J Neurointerv Surg 2018;10:978-82

10 Sirakov S, Sirakov A, Minkin K, et al. Early clinical experience with Cascade: a novel temporary neck bridging device for embolization of intracranial aneurysms. J Neurolntervent Surg 2019. 